\title{
The garnet placer deposit from SE Spain: industrial recovery and geochemical features
}

\author{
1 Dpto. de Geología. Museo Nacional de Ciencias Naturales, CSIC. José Gutiérrez Abascal, 2. 28006 Madrid, Spain; \\ E-mail: martinezfrias@mncn.csic.es \\ 2 Dpto. de Cristalografía y Mineralogía. Facultad de C.C. Geológicas, Universidad Complutense de Madrid. 28040 Madrid, Spain; \\ E-mail: lunar@eucmax.sim.ucm.es \\ 3 Centro de Astrobiología. Instituto Nacional de Técnica Aeroespacial. Edificio S-18. Ctra de Torrejón a Ajalvir. \\ 28850 Torrejón de Ardoz, Spain.
}

\begin{abstract}
The only economic deposit of garnets in Spain is located in the Almería province (SE Spain), forming part of the Neogene Volcanic Complex of El Hoyazo. Due to the high quantity and diversity of the almandine garnets, this area is unique. Garnet occurs as isolated euhedral crystals in the volcanic rock, as the principal component of metapelitic xenoliths in dacite, and as a terrigenous deposit formed by the erosion of the volcanic dome. In this work, we provide new mineralogical and geochemical data, which should be taken into account during the processing and recovery of the garnet placer.
\end{abstract}

\section{Economic importance of the garnet placer}

Almandine $\left(\mathrm{Fe}_{3} \mathrm{Al}_{2} \mathrm{Si}_{3} \mathrm{O}_{12}\right)$ is the most common variety of garnet. It is also the variety preferred for industrial purposes because of a combination of superior chemical and physical characteristics such as high resistance to degradation, high specific gravity (4.32) and hardness (7.0-7.5). These characteristics make garnet a high-quality abrasive used in the manufacture of sandpaper, abrasive wheels, polishing/ lapping grains, powders, grits, and other industrial products. Other applications deal with water filtration systems, additive in grouting cements for oil-well drilling applications, low- to mediumlevel radiation shielding, and the cleaning and conditioning of soft metals (Andrews, 1995; Harben and Kuzvart, 1996).

\section{Garnet placer deposit}

The garnet-rich sands of El Hoyazo (Almería province, SE Spain) are located to the south of their source area: El Hoyazo Volcanic Complex (Figure 1A). The Complex consists of an erosional remnant of a peraluminous volcanic-subvolcanic dacite dome (a pipe and surrounding block lava) of the high-K calc-alkaline type, which forms a shallow hill. The age of the eruption has been estimated at 11.9 Ma (Munksgaard, 1984). The dacite dome was covered by Messinian reef deposits (Dabrio et al., 1981). Subsequent erosion excavated a large depression through the overlying limestone cover into the softer volcanic rock. The result is a roughly circular craterlike depression, with an area of approximately $0.7 \mathrm{~km}^{2}$. This is cut by a gorge through which the Rambla de las Granatillas reaches the plain of Cuenca de Níjar.

The Quaternary alluvial fan, which forms the placer deposit, covers an area of $1 \mathrm{~km}^{2}$ and has a maximum thickness of $40 \mathrm{~m}$ (IGME, 1981). Garnets are found loose in layers 5-50 cm thick and up to $50 \%$ in volume garnet-rich (Figure 1B). The richest beds lay at $0.5-1.5 \mathrm{~m}$ from the base of the sand body. The composition of the El Hoyazo garnet does not differ very much from that found in other typical industrial deposits (Table 1). At the beginning of the twentieth century, garnet exploitation reached an all-time high, which peaked in 1933. From 1996 until very recently, a private company,
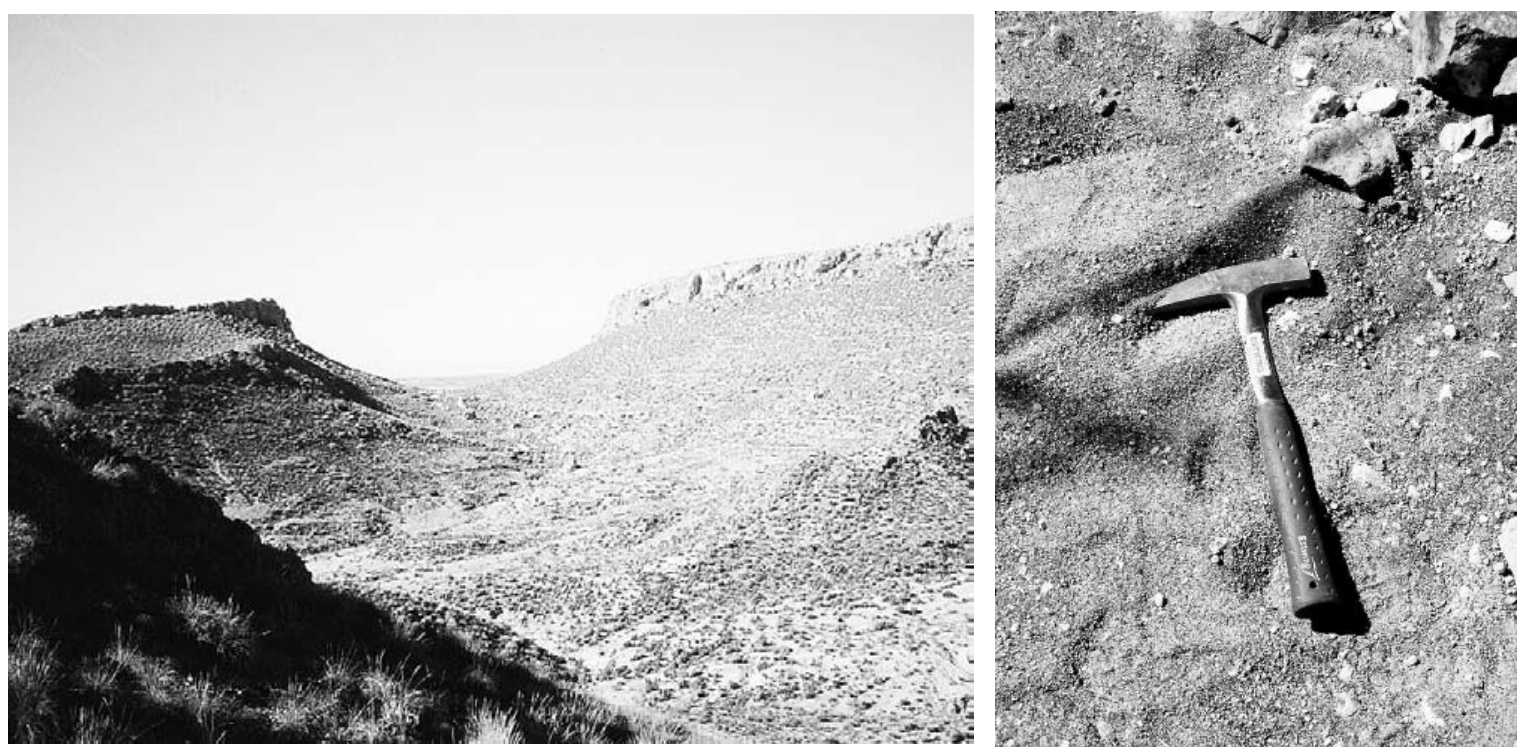

Figure 1 A(left) - General view of El Hoyazo Volcanic Complex. Note that erosion excavated a large depression through the overlying limestone cover into the softer volcanic rock. B(right) - Garnet-rich sands. Garnets are found loose in layers 5-50 cm thick and up to 50\% in volume garnet-rich. The richest beds lay at 0.5-1.5 $\mathrm{m}$ from the base of the sand body. 
Table 1 Chemical compositions of industrial garnet (wt \%) from different world producers. Modified from Harben and Kuzvart, 1996.

\begin{tabular}{l|c|c|c|c|c}
\hline & $\begin{array}{c}\text { Port Gregory, } \\
\text { Australia } \\
\text { Placer deposit }\end{array}$ & $\begin{array}{c}\text { Tamil Nadu, } \\
\text { India } \\
\text { Placer deposit }\end{array}$ & Placer deposit & $\begin{array}{c}\text { Idaho, USA } \\
\text { Cohemia, } \\
\text { Metamorphic }\end{array}$ & Níjar, Spain \\
\hline $\mathrm{SiO}_{2}$ & 36.10 & 35.10 & 39.00 & 36.92 & 37.82 \\
$\mathrm{Al}_{2} \mathrm{O}_{3}$ & 20.40 & 21.60 & 26.00 & 21.17 & 19.34 \\
$\mathrm{FeO}$ & 29.80 & $32.90^{*}$ & $30.00^{*}$ & $36.70^{*}$ & $37.12^{*}$ \\
$\mathrm{Fe}_{2} \mathrm{O}_{3}$ & 1.70 & - & - & - & - \\
$\mathrm{TiO}_{2}$ & 1.80 & 0.55 & - & 0.06 & 0.05 \\
$\mathrm{MnO}$ & 1.05 & 0.53 & 2.00 & 0.37 & 1.55 \\
$\mathrm{CaO}$ & 1.55 & 1.84 & 2.00 & 0.87 & 0.99 \\
$\mathrm{MgO}$ & 6.00 & 7.40 & 2.00 & 3.92 & 2.80 \\
$\mathrm{Total}$ & 98.40 & 99.92 & 101.00 & 100.01 & 99.67 \\
\hline
\end{tabular}

Note: * total Fe.

Garnetkao, S.L., had recommenced the exploitation intermittently. Garnet grains are easily recovered from the ore sands for industrial applications, principally as a mineral abrasive. The method of beneficiation is quite simple and inexpensive: the collection of the garnetrich sands is followed by screening, magnetic separation, washing, jigging and spiral concentration, crushing and finally, classification. The end product is an 80-mesh garnet-rich powder, and the average yield was estimated at 6t/day (Lunar et al., 1997, 1999; Benito et al., 1998).

\section{A}

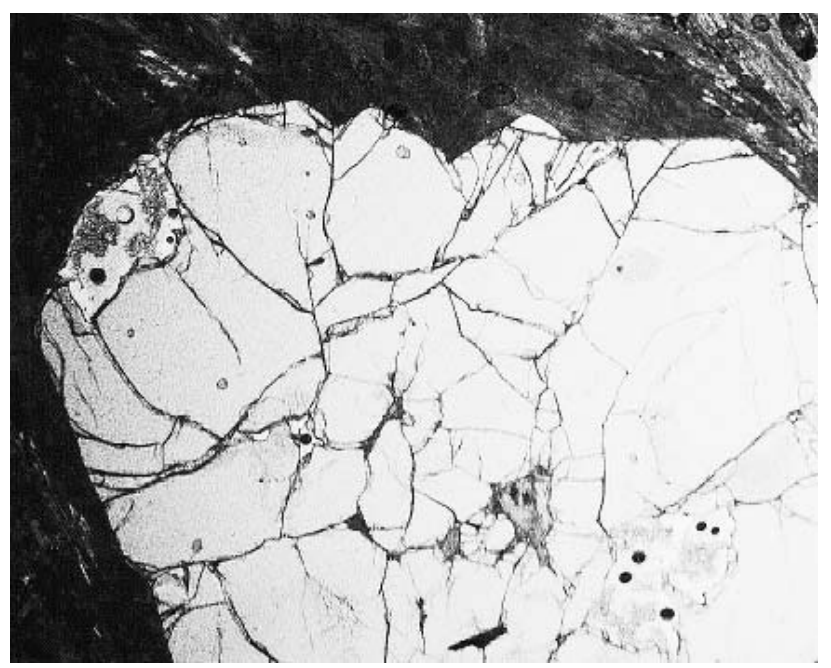

C

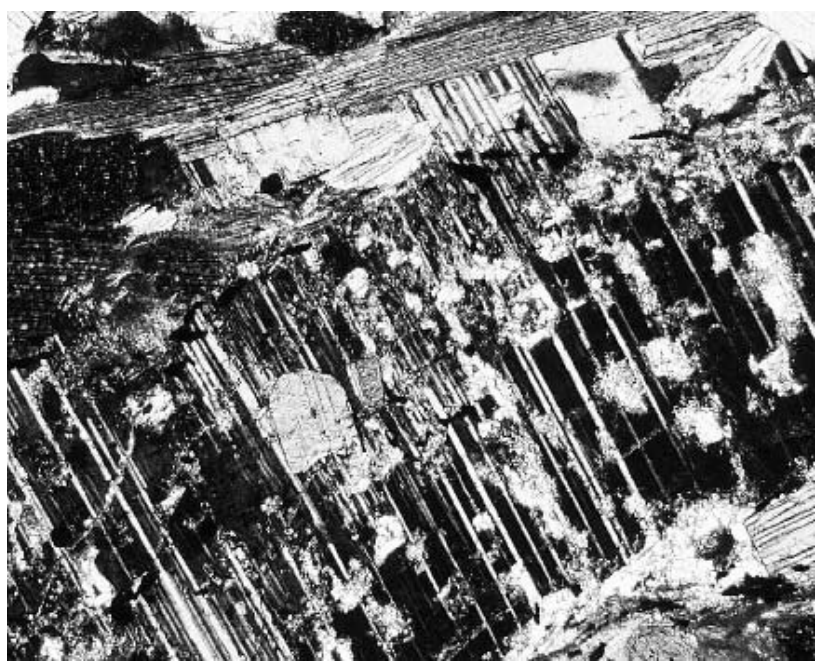

\section{Source area rocks}

El Hoyazo is part of a volcanic and metallogenetic belt that extends from the Cabo de Gata to Mar Menor, in the eastern border of the Betic Ranges (SE Spain). This belt comprises five series of increasingly younger volcanic rocks: calc-alkaline, high-K calkalkaline, shoshonitic, ultrapotassic and alkali basalts. The volcanic activity began in the late Burdigalian/early Langhian and ended in the Messinian (Bellon and Brousse, 1977; López Ruíz and Rodríguez Badiola, 1980; Bellon et al., 1983; Di Battistini et al., 1987).

The El Hoyazo dacite is porphyritic and has a glassy matrix (50 vol.\%), which contains minerals from magmatic crystallization (mainly plagioclase (10-15 vol.\%), cordierite (10 vol.\%) and biotite (8-10 vol.\%), and subrodinately sillimanite, quartz, hornblende, pyroxene, hercynite, apatite, zircon and opaques); xenoliths (60\% of metapelitic aluminium-rich restite material and $40 \%$ of several types of igneous rocks); and monocrystals derived from the xenoliths (Zeck, 1968, 1970, 1992; Molin, 1980).

The garnet-biotite-sillimanite gneissic xenoliths are the most important type of inclusion, not only because they are the most abundant, but also because they include garnet in their mineralogy. The alternation of biotite and sillimanite (fibrolite) defines a foliation.
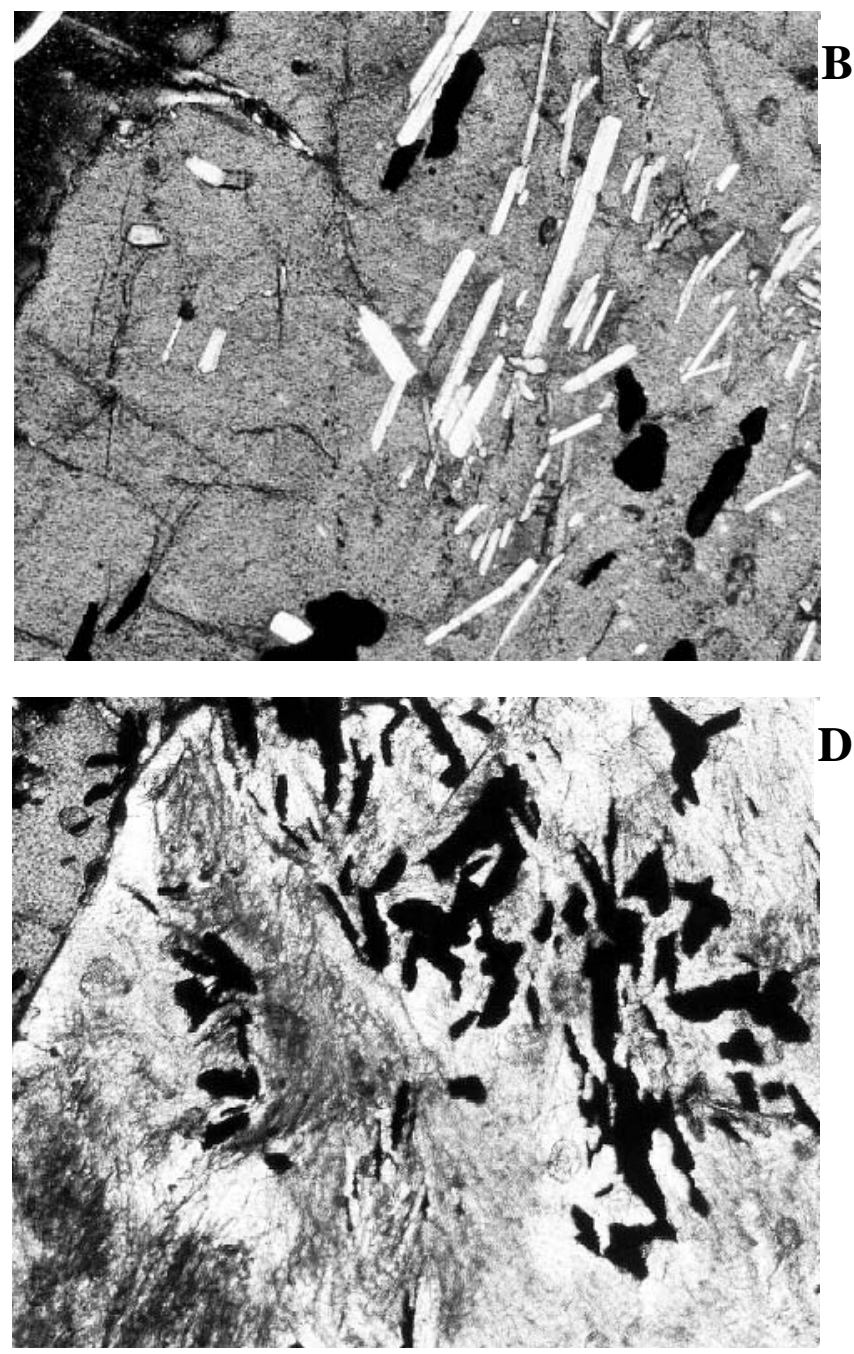

Figure 2 Some selected features of the main minerals which form part of the paragenesis of the gneissic xenoliths: a) garnet crystals displaying tiny inclusions of quartz, biotite and zircon; b) acicular sillimanite randomly included in a cordierite grain; c) clouded plagioclase associated with biotite, and d) graphite in fibrous sillimanite. 
The mineral assemblage also includes cordierite, plagioclase, potassium feldspar (sanidine), hercynite, apatite, corundum, zircon, quartz, and opaques (graphite, ilmenite and magnetite) (Figure 2). These xenoliths have been interpreted as restites, formed by extraction of 30-60 wt.\% rhyolitic melt from a pelitic protolith. The protolith was probably a garnet-biotite phyllite from the surrounding Alpujárride metamorphic complex (Cesare et al., 1997).

\section{Properties of the industrial garnets}

We have confirmed the physical and mineralogical properties of the garnets in the dacite and the garnets in the gneissic xenoliths. Both show similar sizes $(2-10 \mathrm{~mm}$ in size in the lava; up to $1.5 \mathrm{~cm}$ in the xenoliths), red colour, euhedral or subhedral habit, unitary cell size $\left(\mathrm{a}_{\mathrm{o}}=11.537 \pm 0.01 \AA\right.$ and $11.535 \pm 0.01 \AA$, respectively $)$, refraction index $(\mathrm{n}=1.809)$, mineralogical composition (Alm70-82 Pir6-16 Gros $_{15-2}$ Espes $_{11-1}$ and Alm $70-82$ Pir $_{9-15}$ Gros $_{15-2}$ Espes $_{8-1}$, respectively) and zonation ( $\mathrm{Fe}$ and $\mathrm{Mg}$ increasing, and $\mathrm{Ca}$ and $\mathrm{Mn}$ decreasing from core to rim). There are, however, differences in the mineral inclusions: garnets from the dacite contain biotite, sillimanite (fibrolite), quartz and zircon; garnets in the gneissic xenoliths also contain amoeboidal to subhedral Ce-rich (32.5 wt.\%) monazite, and xenotime, which have not been detected in the garnets from the volcanic rocks (Figure 3) (Benito et al., 1998; Muñoz-Espadas, 1999). Monazites occur as amoeboidal-to-elongated inclusions, from around 10 $\mu \mathrm{m}$ to $120 \mu \mathrm{m}$, hosted not only in garnet crystals, but also in the matrix of the xenoliths.

Oxygen isotopic values $\delta^{18} \mathrm{O}$ range from +11.5 to $+11.7 \%$ o (Martínez-Frías et al., 1998). Radiogenic isotope data yields a $\mu$ $\left({ }^{238} \mathrm{U} /{ }^{204} \mathrm{~Pb}\right)$ value that is much lower for garnets from the dacite (0.146), than in the ones from the gneissic xenoliths (24.9-33.5). This could be explained by the high amount of ${ }^{204} \mathrm{~Pb}$ in the former (226.8 ppm of total $\mathrm{Pb}$ ), compared with a maximum of $3.391 \mathrm{ppm}$ in the latter. Other rates using $\mathrm{Pb}, \mathrm{Sm}$ and $\mathrm{Nd}$ isotopes, on the other hand, are very similar for garnets from both sources (Table 2). The Sm-Nd estimated age of the garnets is $313 \pm 52 \mathrm{Ma}$, which coincides with the age of the protolith of the gneissic xenolith from the Alpujárride metamorphic complex (Muñoz-Espadas, 1999).

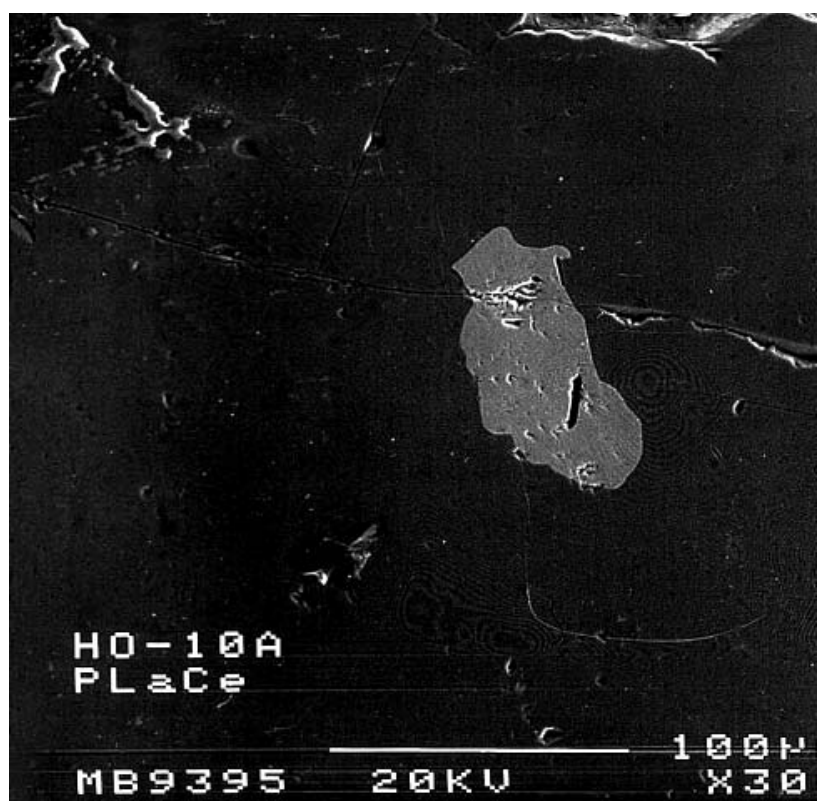

Figure 3 SEM picture (JSM-6400) of an irregular inclusion of monazite hosted in a garnet from the metamorphic xenoliths.
Table 2 Radiogenic isotopes data of the El Hoyazo garnets.

\begin{tabular}{cccc}
\hline Element/unit & GL (lava) & GE1 (xenolith) & GE2 (xenolith) \\
\hline$[\mathrm{Sm}], \mathrm{ppm}$ & 2.297 & 5.224 & 3.878 \\
{$[\mathrm{Nd}], \mathrm{ppm}$} & 9.342 & 24.64 & 17.27 \\
{$[\mathrm{~Pb}], \mathrm{ppm}$} & 226.8 & 3.391 & 1.329 \\
{$[\mathrm{U}], \mathrm{ppm}$} & 0.5197 & 1.325 & 0.6961 \\
${ }^{87} \mathrm{Sr} /{ }^{86} \mathrm{Sr} \pm 2 \sigma$ & & $0.729132 \pm 21$ & $0.715634 \pm 17$ \\
${ }^{147} \mathrm{Sm} /{ }^{144} \mathrm{Nd}$ & 0.14914 & 0.12858 & 0.13622 \\
${ }^{143} \mathrm{Nd} \mathrm{d}^{144} \mathrm{Nd} \pm 2 \sigma$ & $0.512016 \pm 6$ & $0.511974 \pm 5$ & $0.511989 \pm 6$ \\
${ }^{206} \mathrm{~Pb} /{ }^{204} \mathrm{~Pb}$ & 18.485 & 18.571 & 18.564 \\
${ }^{207} \mathrm{~Pb} /{ }^{204} \mathrm{~Pb}$ & 15.641 & 15.665 & 15.661 \\
${ }^{208} \mathrm{~Pb} /{ }^{204} \mathrm{~Pb}$ & 38.475 & 38.750 & 38.753 \\
$\mu$ & 0.146 & 24.9 & 33.5 \\
\hline
\end{tabular}

Note: $\mu={ }^{238} \mathrm{U} / 204033 \mathrm{~Pb} ; \sigma=$ mean weighted deviation.

\section{Controversy on the origin of the garnets}

Two different mechanisms have been proposed to explain the origin of garnets in the volcanics of El Hoyazo: direct crystallization from a silicate melt; and derivation as restitic monocrystals from metapelitic xenoliths. The former hypothesis was proposed by López Ruíz et al., 1977, based on the different zonation of the garnets from each source. The latter was initially suggested by Zeck, 1968, 1970, who stressed the similar textural and mineralogical characteristics of the garnets in lava and xenoliths, and regarded the former as monocrystal inclusions. This idea was later supported by Molin, 1980 and Munksgaard, 1985, who found no differences in garnet zoning patterns.

Although our study mostly confirms the mineralogical and textural characteristics of the El Hoyazo garnets, new differences were identified - REE-bearing minerals were detected only in garnets in the gneissic xenoliths. In addition, the different value of $\mu$ and total $\mathrm{Pb}$ are at odds with the restitic monocrystal hypothesis, suggesting a different origin for the garnets from both sources.

\section{Acknowledgement}

The work presented here forms part of NATO programme CRG 960014 and has been partly co-financed by project PB97-1230 of the Spanish "Dirección General de Investigación Científica y Técnica (DGICYT)". Thanks are given to M. Harffy for correcting the English version, José Arroyo for drawing the figures, and Rogelio Sánchez and Jesús Muñoz for the photographic compositions. Special thanks are extended to J.M. Fidalgo (Garnetkao, S.L.) for his permission to sample the area.

\section{References}

Andrews, P.R.A. 1995 The beneficiation of Canadian garnet ores at CANMET: CIM Bulletin, v. Nov/Dec, pp. 55-59.

Bellon, H., and Brousse, R., 1977, Le magmatisme périméditerranéen occidental. Essai de synthèse: Bulletin de la Société Géologique de France, v. 19, pp. 469-480.

Bellon, H., Bordet, P., and Montenat, C., 1983, Chronologie du magmatisme néogéne des Cordillères Bétiques (Espagne méridionale): Bulletin de la Société Géologique de France, v. 25, pp. 205-217.

Benito, R., Martínez-Frías, J., Lunar, R., and Wolf, D., 1998, El Hoyazo: a unique garnet-rich volcanic complex in southeast Spain: TransactionsInstitution of Mining and Metallurgy. Section B. Applied Earth Science, v. 107, pp. B158-B164.

Cesare, B., Salvioli Mariani, E., and Venturelli, G., 1997, Crustal anatexis and melt extraccion during deformation in the restitic xenoliths at El Joyazo (SE Spain): Mineralalogical Magazine, v. 61, pp. 15-27.

Dabrio, C.J., Esteban, M., and Martín, J.M., 1981, The coral reef or Níjar, Messinian (Uppermost Miocene), Almería Province, S.E. Spain: Journal of Sedimentary Petrology, v. 51, n. 2, pp. 0521-0539. 
Di Battistini, G., Toscani, L., Laccarino, S., and Villa, I.M., 1987, K/Ar ages and the geological setting of calc-alkaline volcanic rocks from Sierra de Gata, SE Spain: Neues Jahrbuch Fur Mineralogie Monatshefte, v. H8, pp. 369-383.

Harben, P.W., and Kuzvart, M., 1996, Industrial Minerals: A Global Geology. Industrial Minerals Information LTD. Metal Bulletin PLC, London, pp. 462.

IGME. (1981). Mapa geológico y minero de España. Map 1046: Carboneras. Scale 1:50.000.

López Ruíz, J., Rodríguez Badiola, E., and García Cacho, L., 1977, Origine des grenats des roches calco-alcalines du Sud-Est de l'Espagne: Bulletin volcanologique, v. 40, pp. 141-152.

López Ruíz, J., and Rodríguez Badiola, E., 1980, La región volcánica neógena del sureste de España: Estudios Geológicos, v. 36, pp. 5-63.

Lunar, R., Martínez-Frías, J., Benito, R., and Wolf, D., 1997, Los granates como guía de exploración y materia prima: El ejemplo del Hoyazo de Níjar en el cinturón metalogenético del SE Ibérico: Geogaceta, v. 22, pp. 113-116.

Lunar, R., Martínez-Frías, J., Benito, R., and Wolf, D., 1999, Nijar and the garnets of Europe: Geotimes, v. 44, n. 1, pp. 22-27.

Martínez-Frías, J., Lunar, R., Benito, R., Wolf, D., Delgado, A., and MuñozEspadas, M.J., 1998, The controversy over the origin of garnets from the

María-Jesús Muñoz-Espadas is a Ph.D. Student at the Dept. of Geology of the Museo Nacional de Ciencias Naturales (CSIC). She received a B.Sc. in Geology in 1998, and a M.S. in Mineralogy in 1999 from the Universidad Complutense de Madrid. She is currently researching on Space Mineralogy.

Jesús Martínez-Frías is research staff scientist in the Centro de Astrobiología (CSIC-INTA). He gained his B.Sc. in Geology in 1982 and his Ph.D. in Mineral Deposits in 1986 from the Universidad Complutense de Madrid. Presently he is a member of the Commission on Science and Technology for Development of the United Nations, and Spanish representative in the Impact Program of the European Science Foundation.

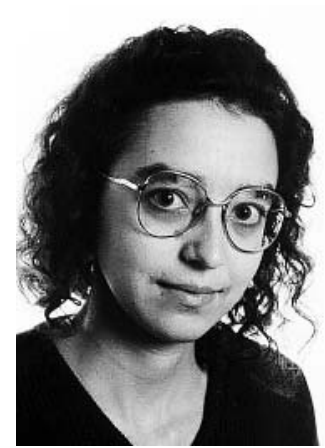

Rosario Lunar holds a B.Sc. in Geology (1973) and Ph.D. in Economic Geology (1976) from the Universidad Complutense de Madrid. Since 1988 she has been a Professor of Mineral Deposits in the Department of Crystallography and Mineralogy in that university.

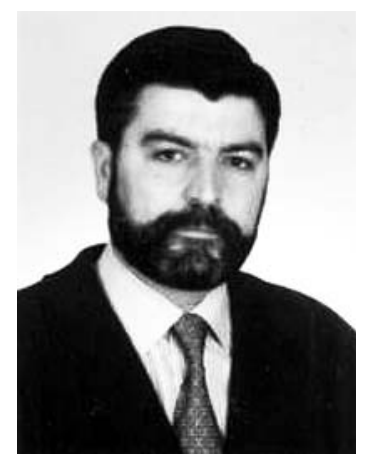

El Hoyazo volcanic Complex: New textural, chemical and isotopic data (abs): Terra Nova, v. 10, pp. 38.

Molin, D., 1980, Le volcanisme miocène du Sud-Est de l'Espagne (Provinces de Murcia et d'Almeria). Ph.D. Thesis, Paris Univ, pp. 289.

Munksgaard, N.C., 1984, High $\delta^{18} \mathrm{O}$ and possible pre-eruptional Rb-Sr isochrons in cordierite-bearing volcanics from SE Spain: Contributions to Mineralogy and Petrology, v. 87, pp. 351-358.

Munksgaard, N.C., 1985, A non-magmatic origin for compositionally zoned euhedral garnets in silicic Neogene volcanics from SE Spain: Neues Jahrbuch Fur Mineralogie Monatshefte, v. H-2, pp. 73-82.

Muñoz-Espadas, M.J., 1999, Tesis de Licenciatura. Univ. Complutense de Madrid, pp. 135

Zeck, H.P., 1968, Anatectic origin and further petrogenesis of almandinebearing biotite-cordierite-labradorite-dacite with many inclusions of restite and basaltoid material, Cerro del Hoyazo, SE Spain. Ph.D. Thesis, Amsterdam Univ, pp. 161.

Zeck, H.P., 1970, An erupted migmatite from Cerro del Hoyazo, SE Spain: Contributions to Mineralogy and Petrology, v. 26, pp. 225-246.

Zeck, H.P., 1992, Restite-melt and mafic-felsic magma mixing and mingling in an S-tipe dacite, Cerro del Hoyazo, southeastern Spain: Transactions of the Royal Society of Edinburgh, Earth Sciences, v. 83, pp. 139-144.

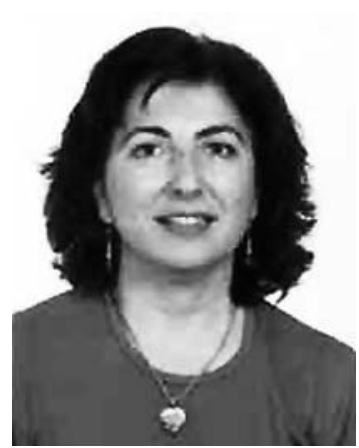

